\title{
1.4. COUNTERPRODUCTIVE BEHAVIOUR IN ORGANIZATIONS: THEORETICAL BACKGROUND AND EMPIRICAL IMPLICATIONS
}

\begin{abstract}
Summary
Problems related to counterproductive behaviour within organizations can be included in sciences on management and organization, namely in organizational behaviour. Human aspect of company functioning is difficult to overemphasize, as the regularities that steer human behaviour within a company must take into account the so-called humanistic factor (the whole symbolic sphere where a man exists, a sphere which is an inherent element of organizational reality). This sphere influences the decision making process to a great extent, what according to some authors is an essence of management.

The analysis will be based on the following definitions of dysfunctional behaviours within an organization 'dysfunction and pathology which drive men are a state of disappearance or not establishing social norms like legal, ethical or professional. They refer to individuals and broader structures, where individuals transfer harmful behaviours (both intended and not intended). They may contribute to induction of unexpected behaviours. The actions which are contrary to the expected ones, in other words - referring to the praxeological terminology - are counterproductive and they prevent organizations from reaching their goals.

The aim of the analysis is to create a theoretical model that would explain the emergence of counterproductive actions within organizations existing in a turbulent environment. The second aim is to indicate methods of management allowing prevention of organizational pathologies. The pro-productive organization model will be approached from the perspective of strategic management, which is targeted mainly at achieving and maintaining competitive supremacy. The outcome of the analysis is to indicate directions of empirical research and to pose research worth-testing hypothesis.
\end{abstract}

Keywords: strategic management, counterproductive behaviour, organizational misbehaviour, ethical leadership

\section{Introduction}

In the present study, attention will be focused on the problem of counter-productive and dysfunctional behaviours within an organization. This issue will be covered from the perspective of strategic changes in an organization forced to act in conditions of discontinuous environmental changes. There is a common belief that the source of the largest turbulence within an organization comes from its environment. Even violent internal changes within an organization i.e. owner change, conflict or crisis within organizational leadership - these are always, to some extent under control of its members and can be mastered before disclosing their destructive power. External changes are different. The organization has no control over them, it cannot be predicted when changes may occur nor the nature of these changes (Romanowska, 2010). Extremely competitive and changing environment requires the organization to have the previously unknown competences involving rapid response to signals coming from the environment. The ability to undertake such actions and making decisions in 
conditions where it's difficult to estimate the risk - these are the sources of numerous tensions, which are a subject of both system of social organizations and the people who work there. A man who acts in a constantly uncertain environment is looking for something certain, some niche, where he would feel safe. If the organization does prepare mechanisms to counteract such tensions, then counterproductive behaviour begins to perform this function, especially informal groups of interest.

This issue is important for several reasons. Firstly, from the perspective of organization employing workers who manifested a counterproductive behaviour. It happens that such behaviours are transferred from the outer environment, i.e. from the culture of a local community. Secondly, this issue is also important from the point of view of an employee, as counterproductive behaviours are often a form of adaptation to an organizational pathology and can cause moral conflicts, especially when they are forced by a group of employees. Counterproductive Work Behaviour can be recognized in the context of the organizational stress theory, according to which organizational tensions, interpersonal conflicts and the visible injustice are stressors and the counterproductive actions are just an adaptive response (Fox, Spector and Miles 2001. p. 291). At this point, it is worth to emphasize the importance of sense of justice in organizations and its impact on productivity (Macko, 2009).

\section{Counterproductive behaviours - a theoretical background}

Problems, which are related to the counterproductive behaviour in the organization, include the area of sciences on management and organization, which is called the organizational behaviours. The human aspect of the organization is difficult to overestimate, as the regularities which drive human behaviour in a company must include the so-called humanistic factor, primarily the entire symbolic sphere (where a man is immersed) and which is an integral element of the organizational reality. This sphere substantially affects the decision-making process, which according to some authors is an essence of management.

Considering the nature of the management one may enumerate the following dimensions (Bhattacharyya, 2009, pp. 5-6):

- productivity orientation - Frederick Winslow Taylor and John F. Mee were the pioneers of this approach. In terms of this approach an increase in productivity is the main goal of management.

- human relations orientation - pioneers: Lawrence A. Appley and Harold Kootz. In this approach, attention is focused mainly on the interpersonal relations within an organization.

- Decision-making orientation - the essence of management comes down to making decisions. Pioneers: Ross Moore and Stanley Vance.

- leadership orientation - according to this orientation leadership is the most important part of management. Pioneers: Donald J. Clough and Ralph C. Davis.

- process orientation - management is seen as a process. Even the organization itself is rather a process than a structure (Czarniawska, 2010).

It should be emphasized that the perspective of human relationships does not treat those a subject of management. Objectives are always outside the organization. It is assumed, however, that relationships are one of the vital resources of an organization. 
They are a key to the effectiveness of the entire management process, and shaping them deliberately and purposefully brings the organization closer to the success. Pathologies in this area - on the other hand - they are dysfunctional and move away from the organization's objectives. However, in accordance with the functional paradigm, the question should be raised about the function of pathologies. Every human action in this paradigm has a particular role. The distinction between function and dysfunction is relative. It means that calling any action functional or dysfunctional depends on whether it leads to the objective, to achieve the goal for which the company was established, or maybe completely different, when it leads to a goal which is contrary to the intended one. This understanding of functions and dysfunctions in management determines the role of the manager. "(...) manager's essential skill is a correct diagnosis of the company's condition, sources of difficulties and successes, future opportunities and risks of development, the strengths and weaknesses of the company." (Romanowska, 1995, p. 10)

Organizational pathologies represent the weaknesses of the company and are one of the main sources of difficulties in achieving the objectives and at the same time they are a significant barrier limiting the development, which is a key indicator of health of any organization. The ability to diagnose organizational pathologies and to prevent them is an important aspect of managerial functions.

This analysis will be based on the following definitions of dysfunctional behaviour within the organization - "dysfunction and pathology of leadership are a state of decay or failure in establishing legal, ethical, professional norms, and more generally social norms and apply to both individual people and the wider structures, where individuals carry adverse effects both knowingly and unknowingly. They may contribute to induce of a contrary behaviour to the expected one." (Chmal, 2007, p. 9) Behaviour, which is contrary to the expected ones, is - referring to the praxiological terminology - a counterproductive behaviour, it does not allow an organization to achieve its goals. Kieżun has a less complex definition of pathology in an organization (the term of dysfunction and pathology will be used interchangeably in this paper): "Pathology of the organization is relatively permanent disability of an organization, which results in the waste exceeding the limits of a social tolerance." (Kieżun, 1997, p. 376) According to this definition, pathological decisions are the ones which determine behaviour whose effect is an excessive consumption of resources in achieving organizational goals, or even in extreme cases, consumption of these resources without achieving the goals. In order to properly assess the "excessive resource consumption", one should have a reference point allowing the comparison of two management processes, both requiring a similar amount of resources. The reference point is not required in case of the total ineffectiveness, meaning when the target has not been achieved in the slightest degree. Without seeking the reference point, even a minor consumption of resources can be called a waste. Can we immediately call every single waste a pathology and an effect of counterproductive behaviour? It seems not. It is difficult to talk about the wastefulness if resources are wasted due to a non-culpable managers lack of knowledge, or due to making decisions in high-risk conditions. This phenomenon occurs when dysfunctional behaviours become "needed" (in its own way) in the organization, when they have specific functions that are in conflict with the 
basic function. This happens, for example, when some of the functions and structures in management are a subject of autonomous processes. Reporting is a good example, as people complain on it in almost every organization. Its purpose is to serve each organization, especially the process of achieving goals, but sometimes it becomes an "art for art's sake", when it gives certain organizational units a control over the organization as a whole. A lot of information is collected 'just in case' and when someone is looking for such important data, it turns out that one needs create it from the beginning, just because this particular data was never collected before.

Organ and Bateman understand organizational behaviour as follows: OB refer to the behaviour of individuals and groups in an organizational environment. In organizations, people perform their duties, do business, gossip, tease others, make decisions, argue, and commit despicable and heroic deeds. When these behaviours a refer to an organization, when they influence the functioning of the organization and when are shaped by the organization. They can be incorporated into these phenomena, which are collectively referred to as an organizational behaviour. (Organ and Bateman, 1991, p. 5) According to this broad understanding of organizational behaviour, functional and dysfunctional behaviour can be added to this group. From the perspective of Organization Behaviour as an object of scientific analysis, both types of behaviour are equally interesting and important in the management of the organization. To sum up the deliberations on the counter-productive behaviour, it should be noted that its essence lies in the "intentional and harmful influence on the organization and its members. These include certain open activities, such as aggression and theft, as well as passive and intentional lapse in respecting the instructions or an inaccurate performing duties. (...) The common feature of all the counterproductivity definitions is the harm it makes to the organization as a whole by a direct negative influence on its functioning or its ownership, or hurting its employees in a way which reduces their effectiveness. (Fox, Spector and Miles, 2001, p. 292)

An overview of definitions made by Fox, Spector and Miles indicates three harmful areas of counter-productive behaviour : functioning of the organization, its property and welfare of its employees. Lack of respect for these three important aspects of functioning of the organization, conducted by a deliberate reduction of the effectiveness of the management process (i.e. Incorrect coordinating of actions), wasting property (i.e. lack of attention to equipment, or even theft) and activities to detriment the employees (i.e. unfair assessment or remuneration). In this paper the abovementioned actions will be referred to as a counterproductive behaviour. Such actions can be undertaken by both employees and employers/managers.

\section{The concept of a healthy organization}

The analysis of counterproductive behaviour carried out so far concentrated mainly on the phenomenon of organizational pathologies. It is worth to note a more constructive approach, namely the concept of a 'healthy organization'. Joseph Penc defined the term in the following way: "it seems that a healthy organization is an efficient organization in the praxeological sense. It is also capable of removing all the difficulties that stand or may stand in the way of its development and harmonious relationship with the environment of its actions. So this is an organization which is 
sensitive to innovation and change, it is able to generate and implement them, it competes due as if has more values to offer to the customer, it is friendly to both its employees and the environment." (Penc, 2001, p. 12) While the concept of organizational pathology became common in the subject literature, the concept of a healthy organization is still uncommon. Stocki $(2005$, p. 375) also uses this term, he writes about "the anatomy of a healthy organization." Medical analogies which increasingly emerge may focus the attention on the subject. Definition made by Penc is interesting, as it draws attention to the positive aspects of a 'healthy organization' (inter alia it is supposed to be able to the adaptive change) and not limited to the absence of a pathology. Kiezun writes about the 'health of an organization'. This raises a further semantic problem: what is the health of the organization, as we are always revolving around the considerations of an organization. We have a number of both US and Polish considerations. The concept presented by Bennis (1966) and Likert (1967) are particularly developed. According to Bennis a basic measure of organizational health is the ability to adapt to altering conditions and to changes in the environment. This ability is a function of the development of a spirit of research. (Kieżun, 1997, p. 375) Kieżun remains in the circle of adaptive changes, in other words, in the area of learning organizations. 'Learning' or a 'smart' organizational become the same model - an ideal type of a healthy organization. Adaptation means learning, therefore it one of the most important management functions in an organization. Dohasz, Fudaliński, Kosala and Smutek put it as follows: "Management should lead to the fact that the organization is capable of learning, in other words, to adapt to changing environmental conditions." (Dohasz et al., 2009, p. 47) Another important issue connected to the concept of healthy organization is trust but this subject needs separate elaboration. (Robak, 2013)

The issue of a healthy organization can be also seen in the context of organization's ethos. Lewicka and Guzik introduced the concept of the "anatomy of a healthy organization," and they define it as follows: A healthy organization as opposed to a pathological one is characterized by humanity, openness to employees and their needs, it allows the employees to learn from each other and from the managers. The managers do not subordinate the employees, but they cooperate with them, as the aim is to solve problems and act for the good of the company. They allow them to make mistakes, as the conclusions are drawn for the future. Managers also allow employees to take risks (within a certain extent) associated with i.e. new ideas. In a well-functioning and friendly staff, organization there is a principle of liability for both company and employees. There is no space for blame or denial; everyone takes responsibility for ones actions by doing their job as best as they can. A manager is not laissez-faire person, but he is the leader outstanding above the average, being a model to follow. (Lewicka and Guzik 2015)

At first, the introduction of such concepts as 'humanity' and 'openness to employees' sound naive in terms of economic efficiency which is the main criteria for company success. That is just why we should keep these issues in mind not only because human dignity is a fundamental value of a Western civilization, (Mitrus, 2015) but also as shown by numerous studies, recognition of these values in an organization fundamentally affects the efficiency of its employees. Ethical leadership directs 
members of the organization toward goals which are benefits for the organization, its members, stakeholders and the society. In other words, ethical leadership appears to be effective. (De Hoogh and Den Hartog, 2008).

It is worth noting that most publications devoted to assessments of the staff list four types of criteria: eligibility, efficiency, personality and behavioural. (Oleksyn, 2001) Ethical criteria, if presented, are in the groups of personality or behavioural criteria. Yet they are completely detached competences. What use the employer has with an excellent and professional accountant, if the man is dishonest or irresponsible? Some authors write about moral competences, enumerating as follows:

- Actions consistent with the principles, values and beliefs,

- Telling the truth,

- Insistence on what is right,

- Keeping promises,

- Taking responsibility for personal decisions,

- Admitting to mistakes and failures,

- Accepting the responsibility to serve others,

- Actual concern for others,

- An ability to accept one's own mistakes,

- An ability to accept mistakes others make. (Turek and Wojtczuk-Turek, 2011)

These competences are important not only for employees, but especially for the leaders.

\section{Conclusions}

Both management and employees manifest counterproductive behaviours. As the managers have a full authority, they are responsible for employees counterproductive behaviour. From the functional approach these behaviours have an adaptive function to the pathological work conditions.

People management is in a blatant contradiction with a toxic leadership, based on a Roman principle 'divide et impera' (divide and rule). According to this principle, it is the best to rule the subordinates who are conflicted with each other. This type of leadership treats people instrumentally only, what makes a teamwork (which is so important in the contemporary business) highly difficult, and sometimes even impossible.

The emphasis of the excessive and unjustified work competition, increases destructive conflicts and fosters the emergence of one of the largest pathologies in contemporary organizations, namely an organizational stress which is being a source of other pathologies.

\section{References}

1. Bhattacharyya, D.K. (2009): Organizational Behaviour. Concepts and Applications, Oxford University Press, Oxford - New York.

2. Chmal, Z. (2007): Pojęcie dysfunkcji i patologii w życiu społecznym, in: Dysfunkcje i patologie w sferze zarządzania zasobami ludzkimi, red. Z. Janowska, Wydawnictwo Uniwersytetu Łódzkiego, Łódź. 
3. Czarniawska, B. (2010): Trochę inna teoria organizacji, Poltext, Warszawa.

4. De Hoogh, A.H.B., Den Hartog, D. N (2008): Ethical and despotic leadership, relationships with leader's social responsibility, top management team effectiveness and subordinates' optimism: A multi-method study, The Leadership Quarterly no. 19.

5. Dohasz, M., Fudalinski, J., Kosala, M, Smutek, H. (2009): Podstawy zarządzania. Koncepcje strategie - zastosowanie, Wydawnictwo Naukowe PWN, Warszawa 2009.

6. Fox, S., Spector, P.E., Miles,. D. (2001): Counterproductive Work Behaviour (CWB) in Response to Job Stressors and Organizational Justice: Some Mediator and Moderator Tests for Autonomy and Emotions, Journal of Vocational Behaviour no. 59.

7. Hurta, H. (2014): Impact of the Crisis on Leader's Attitude, in: Illes A.B., Dunay A., Słocińska A., New Trends in Management in the $21^{\text {st }}$ Century, Wydawnictwo Wydziału Zarządzania Politechniki Częstochowskiej, Częstochowa.

8. Kieżun, W. (1997): Sprawne zarządzanie organizacją. Zarys teorii i praktyki, Szkoła Główna Handlowa, Warszawa.

9. Lewicka, D., Guzik, G. (2014): Wpływ dysfunkcyjnego zachowania managerów na jakość środowiska pracy $\mathrm{w}$ organizacji, http:/www.google.pl/url?url=http://irbis-nbuv.gov.ua/cgibin/irbis_nbuv/cgiirbis_64.exe\%3FC21COM\%3D2\%26I21DBN\%3DUJRN\%26P21DBN\%3D UJRN\%26IMAGE_FILE_DOWNLOAD\%3D1\%26Image_file_name\%3DPDF/VNULPM_20 14_797_26.pdf\&rct $=$ j\&frm $=1 \& q=\&$ esrc $=$ s\&sa $=$ U\&ei $=$ qYT $\bar{L}$ LVMizKNbzas7gguAJ\&ved $=\overline{0}$ CB MQ̄FjAA_\&sig2=Onay4Jxw4FhzQMrYCYMvxg\&usg=AFQjCNGgIOgSWe_cfmpt68QgkkBC2c3JA (12.01.2015)

10. Macko, M. (2009): Poczucie sprawiedliwości organizacyjnej a zachowania pracowników, Wydawnictwo Naukowe Wydziału Nauk Społecznych Uniwersytetu im. Adama Mickiewicza w Poznaniu, Poznań.

11. Mitrus, L. (s.d.): Godność jako podstawa aksjologiczna praw pracowniczych, https://prawo.amu.edu.pl/_data/assets/pdf_file/0010/175528/dr-hab.-Leszek-Mitrus.pdf (9.02.2015)

12. Oleksyn, T. (1991): Praca i płaca w zarządzaniu, Międzynarodowa Szkoła Menedżerów, Warszawa 2001.

13. Organ, D.W., Bateman, T.S. (1991): Organizational Behaviour, IRWIN, Homewood - Boston.

14. Penc, J. (2001): Kreowanie zachowań w organizacji. Konflikty i stresy pracownicze, zmiany i rozwój organizacji, Agencja Wydawnicza Placet, Warszawa.

15. Robak, E. (2013): The Importance of Organizational Trust Management for the Functioning of Enterprises, in: Illes C.B., Bylok F., Dunay A., Cichobłazinski L., People, Knowledge and Modern Organizations, Szent Istvan Kiadó Nonprofit K.ft., Godollo.

16. Romanowska, M. (2010): Przełomy strategiczne w przedsiębiorstwie, Studia i Prace Kolegium Zarządzania i Finansów, „Zeszyt Naukowy 98, Szkoła Głównia Handlowa W Warszawie”, Warszawa.

17. Romanowska, M. (1995): Zarządzanie strategiczne firmą, Centrum Informacji Menedżera, Warszawa.

18. Stocki, R. (2005): Patologie organizacyjne. Diagnoza i interwencja, Wydawnictwo Wolters Kluwer, Warszawa.

19. Turek, D., Wojtczuk-Turek A. (2011): Kompetencyjne uwarunkowania nieetycznego zachowania pracowników, „Problemy Zarządzania”, vol. 9, 4 (34). 
